\title{
DeCOlONISATION PROCESSES IN THE SOUTH PACIFIC ISLANDS: A COMPARATIVE ANALYSIS BETWEEN METROPOLITAN POWERS
}

\author{
Paul de Deckker
}

The South Pacific islands came late, by comparison with Asia and Africa, to undertake the decolonising process. France was the first colonial power in the region to start off this process in accordance with the decision taken in Paris to pave the way to independence for African colonies. The Loi-cadre Defferre in 1957, voted in Parliament, was applied to French Polynesia and New Caledonia as it was to French Africa. Territorial governments were elected in both these Pacific colonies in 1957. They were abolished in 1963 after the return to power of General de Gaulle who decided to use Moruroa for French atomic testing. The status quo ante was then to prevail in New Caledonia and French Polynesia up to today amidst statutory crises. The political evolution of the French Pacific, including Wallis and Futuna, is analysed in this paper. Great Britain, New Zealand and Australia were to conform with the 1960 United Nations' recommendations to either decolonise, integrate or provide to Pacific colonies self-government in free association with the metropolitan power. Great Britain granted constitutional independence to all of its colonies in the Pacific except Pitcairn. The facts underlying this drastic move are analysed in the British context of the 1970's, culminating in the difficult independence of Vanuatu in July 1980. New Zealand and Australia followed the UN recommendations and granted independence or self-government to their colonial territories. In the meantime they reinforced their potential to dominate the South Pacific in the difficult geopolitical context of the 1980s. American Micronesia undertook statutory evolution within a strategic framework. What is at stake today within the Pacific Islands is no longer of a political nature; it is financial.

* Professeur, Université Française du Pacifique \& Université Libre de Bruxelles. 


\section{Introduction}

The Second World War had a huge impact on the South Pacific Islands : not only were tens of thousands of Japanese and Allied troops stationed there for several years, transforming the mentalities of traditional people who came into forced contact with them, but the war's aftermath also led to the overall conclusion that colonised people should be freed from the relationship of domination that was prevalent in so many countries under colonial regimes, whether in Asia, Africa or the South Pacific.

The United Nations played a major role in defining decolonising processes. First of all, in 1945 the San Francisco Charter set up an international system of trusteeship which amounted to a provisional system of territorial government for colonies whose people were not yet considered as being able to fully govern themselves. Only the territories which were placed under a mandate of the League of Nations at the end of First World War could benefit from the new system. All of them became constitutionally independent between 1957 and 1968, except Papua New Guinea and the former Japanese Pacific territories, which were taken over by the Americans in $1945 .^{1}$

Concerning the other colonies, the San Francisco Charter established some general principles, including the primacy of the inhabitants' interests and the development of their capacity to administer themselves. The Charter did not prescribe any time frame for them to achieve constitutional independence. In the meantime the principle which was to govern future relationships between states was consolidated: the right of people to self-determination.

The anti-colonialism majority which existed within the United Nations since its inception used this principle to submit non self-governing territories to international control and to intervene in time of conflict between colonial powers and independence movements. This pressure was reinforced in 1960 with the adoption of the Resolution on the Right to Independence for colonial countries and territories. ${ }^{2}$ A Committee to organize the implementation of this Declaration was formed, mainly by countries which had just gained independence and which were resolutely hostile to any form of colonialism.

1 Rwanda-Burundi, Sudan, Togo, Cameroon, Swaziland, Tanganyika, Western Samoa and Nauru. Papua New Guinea was to become independent in 1975. The accession to independence of American Micronesia, the Trust Territory of the Pacific Islands (divided into six, later seven districts : Belau, Yap, the Northern Marianas, Palau, Truk, Pohnpei, Kosrae and the Marshall Islands) will be analysed below.

2 United Nations Resolution 1514 of 1960 which declared that lack of social and economic preparedness could not be considered as a barrier to self-determination. 
It should be stated at this stage that the United Nations Organisation, in contrast with the other Organizations which stem from it or which existed before the Second World War and were reactivated in 1945, is quite a complex structure. The Organisation's governing body is usually the General Assembly or the Conference as it is with UNESCO. ${ }^{3}$ Only the UN works through two separate sovereign arms : the General Assembly and the Security Council. The General Assembly is formed by all member countries and they all have equal status within the organization; the General Assembly has full responsibility over all fields and matters which it deals with. The Security Council, on the other hand, is formed by fifteen members of which five are permament. ${ }^{4}$ The ten others are elected for two years by the General Assembly. The Security Council deals with peace and international security ; it acts on behalf of all members of the UN and, as such, takes institutional precedence over the General Assembly in these two fields.

\section{Paving the way towards independence : France}

Five years before Western Samoa became constitutionally independent in 1962, Paris had decided to pave the way to independence for New Caledonia and French Polynesia by enacting a law providing for self-government : the loi-cadre of 23 June $1957^{5}$. Each of the two territories elected its 'governing council' and its own territorial assembly, while a governor appointed by Paris, continued to represent the French State in each territory.The loi-cadre of 1957 took into account events in Indochina, Morocco and Tunisia. It allowed for the first statute of selfgovernment in French colonies, then officially named overseas territories, with real autonomous decision-making powers. Executive councils of government, with ministerial portfolios, were instituted. Implemented by the last governments of the Fourth Republic, this law was a cornerstone for the decolonisation of overseas territories, that would be implemented under the Fifth Republic.

Indeed, when Charles de Gaulle returned to power in 1958, he gave an address in Brazzaville in which he explained the underlying principles of the 'French Commonwealth' he wanted to create : the Communauté française : through the formation of a vast political, economic and defensive network, including all French overseas territories wishing to participate, the Communauté would provide full self-government and free self-determination through referenda, which would soon be organised. De Gaulle defined new institutional structures that would link

3 WHO, ILO, IMF, etc.

4 The permanent members are the US, Russia, China, Great Britain and France.

5 This 1957 loi-cadre applied to all French colonies, especially the African countries for which it was decided to grant independence shortly (Senegal, Ivory Coast, Gabon, Congo, etc.). 
France with its former colonies and, above all, would clearly delineate the question of independence. Overseas territories, if their populations wished, could immediately obtain independence by voting 'No' in the constitutional referendum. Moreover, having voted positively, members of the Communauté, could later negotiate their respective independent constitutions with Paris. ${ }^{6}$

De Gaulle wanted France to have a high profile on the world scene as well as in the Security Council where only nuclear powers really have any weight. With the war in Algeria, it was not possible for the French army to pursue atomic testing in the Sahara desert. French Polynesia was chosen in the early 1960s as being the most favourable zone in which to conduct further testing. In 1963, the French Polynesian Council of Government was abolished, since Charles de Gaulle wanted to prevent any potential movement for autonomy from developing. Because of the proVichy attitude of the Société Le Nickel during World War Two, and its strategic importance for France, in 1963 Charles de Gaulle decided that New Caledonia would get the same constitutional treatment as French Polynesia. Of course, the domino theory was also to be taken into account in this imposition of a status quo ante for the French overseas territories in the Pacific. $^{7}$

France was to become perceived, from then on, as a reactionary power within the Pacific region. But, as Charles de Gaulle put it : "France has no friends, no enemies, just interests".

\section{Australasia : decolonisation}

For New Zealand, like Australia, the end of World War II implied a need to forge new policies as far as their mandated territories or colonies were concerned. During the first part of the 20th century, these two countries had tentatively assumed a position on the world scene as new colonial powers, in an attempt probably to gain some of the imperial grandeur of their 'mother country'. But they lacked experience in colonial management ${ }^{8}$ and had no real military and diplomatic strength. The international scene was changing very rapidly in 1945 and both

6 See on this topic, Paul de Deckker, "France", in K Howe, R Kiste \& B Lal (eds) Tides of History, The Pacific Islands in the Twentieth Century (Allen \& Unwin, Sydney, 1994) 258-279.

7 Wallis and Futuna was a French protectorate up to 1961. It became a French Overseas Territory that year after the organization of a referendum for which the population voted heavily in favour of remaining French.

8 This is particularly the case with New Zealand in Western Samoa as the Mau Movement showed from 1929. See, amongst others, Michael King, Mau, Samoa'as Struggle against New Zealand Oppression (Wellington, Reed, 1984) and Malama Meleisa, The Making of Modern Samoa : Traditional Authority and Colonial Admministration in the History of Western Samoa (Institute of Pacific Studies, University of the South Pacific, Suva, 1987). 
these countries from the Antipodes, isolated at the periphery from the centres of political and economic power, then began to think in terms of regionalism. Both of them were at the origin of the South Pacific Commission - the first body to foster regional development - which was set up in 1947 in Canberra. This political and diplomatic approach was to combine a dual strategy : to keep on playing a major new role within the region and, as such, to secure recognition on the world stage.

New Zealand and Australia were instrumental at the United Nations in pushing forward a commitment to the principle of self-determination for colonised people. This principle subsequently underlay the trusteeship's notions which became predominant with the necessity to conduct non-self-governing territories to either self-governing status or independence.

Under New Zealand control, Western Samoa was to lead this movement in achieving constitutional independence in 1962 according to United Nations Resolution 1514 of 1960 and after an expression of universal suffrage under UN observation explicitly confirmed the Samoan people's wish as well as the implementation of a traditional constitution. ${ }^{9}$

In 1965, the Cook Islands, and later on, Niue in 1974, achieved a status of self-government in free association with New Zealand, although the latter apparently would have preferred the former to become independent. ${ }^{10}$ The traditional leaders of both the Cook Islands and Niue considered that constitutional independence was not realistic and too drastic a solution to their problems (financial subsidies and access for their meagre export products exclusively to the New Zealand market). As more than $20 \%$ of all Cook Islanders and more than $50 \%$ of Niueans were already living more or less permanently in New Zealand, they wanted to lose neither their access to New Zealand not their citizenship. Only Tokelau refused the four options which New Zealand suggested ; the faipule of the three tiny atolls wanted to remain a colony of New Zealand against New Zealand's wish and with the full consent of the inhabitants as the United Nations fact-finding mission in 1976 and 1981 recognised. Without proper resources of their own, the 1700 Tokelauans cannot envisage themselves being anything other than a New Zealand dependency. It is thus clear that in order to comply with the United Nations principles of justice and self-determination for colonised people, New Zealand acted correctly but, as

9 Only matai title holders (traditional chiefs) were able to vote from then on. It is recently that the Western Samoan Constitution changed to allow generalized franchisement or universal suffrage.

10 New Zealand offered four options to its dependencies in accordance with UN Resolution 1514 of 1960 : independence, integration with New Zealand, an independent federation of Polynesian countries (including the Cooks, Niue and Tokelau), self-government in free association with New Zealand. 
stated by Terrence Wesley-Smith : "Political freedom was returned to the colonial peoples in the 1960s and 1970s essentially for the same reason it was removed in an earlier era - to meet the needs of the colonial power".11

This is strongly emphasized in the decolonisation procedure of Nauru, that central Pacific island rich in phosphate deposits which has been exploited jointly by Australia, New Zealand and Great Britain since the First World War when Australian troops took over this $21 \mathrm{~km}^{2}$ island from Germany. Nauruans in the late 1950s challenged this tripartite colonial regime in claiming that the phosphate belonged to Nauruans and not to the colonial rulers. The United Nations' principles did not apply as quickly here as they did with territories without cheap supplies of phosphate needed by Australian, New Zealand and British agriculture. While Australia attempted to displace the Nauruans and resettle them on Curtis Island near the Queensland coast, New Zealand stated that it was not prepared to oppose the UN principles of trusteeship on economic grounds. Nauru became constitutionally independent in 1968 and economically independent two years later after having been obliged to financially acquire all the industrial plant and facilities for phosphate mining. ${ }^{12}$

The giant island of the South Pacific, Papua New Guinea, was partly an Australian trusteeship of the UN as German New Guinea was taken over by Australian military troops in 1915. A mandated territory of the League of Nations, Papua New Guinea became a United Nations trusteeship after World War Two. Canberra gave a strategic importance to that colony which it did not attempt to develop politically or socio-economically. Education had been kept to a minimum level. It is only when the United Nations pressured Canberra to grant independence to this territory which had enormous economic resources that, in the 1960s, something was done to foster the emergence of a local elite in Papua New Guinea. It was Gough Whitlam, then Leader of the Opposition, who clearly stated in 1970 during a visit in Port Moresby that a Labour government would grant independence to Papua New Guinea. But nothing had ever been done by the Australian colonial administration to create a national spirit amongst the 500 or so ethnic groups in Papua New Guinea. When the country became independent in 1975, thanks to the United Nations' efforts and international pressures, secessionist movements emerged in Papua and Bougainville. These two provinces considered

11 Australia and New Zealand Tides of History, The Pacific Islands in the Twentieth Century above n 6, 221.

12 It took years to Nauru to obtain financial compensation in the early 1990s from Australia over the rehabilitation of the worked-out land. Now that the phosphate extraction industry is near the end, the fields being exhausted, what would happen to this population ? Resettlement somewhere else? 
that Australian mining operations were to benefit the provinces and were not to be shared on a national level. These feelings are still present today among the provincial populations and the national State of Papua New Guinea is entangled in extreme difficulties to form and keep the nation together, in spite of decentralisation policies which were implemented. Still today, Australia largely controls the economy of Papua New Guinea and contributes substantially to its national budget.

\section{Withdrawing : Great Britain}

The imperial centre of Great Britain in the South Pacific was Suva, capital of the colony of Fiji. It is mainly from there that were issued general colonial directives over the five other British colonial outposts. ${ }^{13}$ London always perceived the Pacific colonies, except Fiji, as small territories without real economic interest. Their taking over during the 19th century mainly stemmed from colonial rivalry with other metropolitan powers like France or Germany.

In the 1960s Fiji considered that it was time for constitutional changes. The British colonial rulers had imported a labour force from India between 1879 and 1916 to develop the sugar cane industry. By the 1950s Indians outnumbered Fijians with the other races representing less than $10 \%$. London was prepared to grant independence to Fiji but on the basis of the equality of races. Ten years of constitutional preparation were necessary to accomplish this procedure and Fiji became constitutionally independent in October $1970 .{ }^{14}$

The kingdom of Tonga also became again constitutionally independent in 1970 without any difficulties as Tonga had never been formally a British colony. By the mid-1850s the Methodist Church had protected Tongan rights over land in not allowing foreigners freehold in the kingdom they had helped to create. Only a Treaty of Mutual Friendship existed between Great Britain and Tonga which was thus more a protectorate of Great Britain than a colony.

13 The Gilbert and Ellice Islands Colony, Pitcairn, the Kingdom of Tonga, the British Solomon Islands Protectorate and the British-French Condominium of the New Hebrides.

14 The 1987 coup showed clearly that the equality of races was the predominant question and that the 1970 Constitution was only going to be valid as long as Ratu Sir Kamisese Mara remained Prime Minister. Sociologically speaking, Fiji is economically divided into three distinct elements : the Fijian landholders who lease part of their land to the Indian workforce, the Indians get their income from their labour while the government owns the industrial means to transform the cane into sugar and the capacity to export it to the European mrket and Australasia. The Fijians are thus the landlords, the Indians are workers and the Government the capitalist which makes the system workable. 
After Great Britain joined the European Community, by the mid-1970s, London soon decided to grant constitutional independence to the remaining part of its Pacific Empire : the British economy was not flourishing then and London wanted to withdraw from these archipelagoes whose running cost was no longer considered appropriate, especially when it was perceived that the EEC could implement substantial budgetary assistance through the EEC-ACP Lome Agreement. London had thought in the first instance to commit itself on the model linking the Cooks to New Zealand but this idea waned away when it joined the EEC.

The Solomons became constitutionally independent in 1978. The Gilbert and Ellice Islands, ${ }^{15}$ the former being Micronesian, the latter Polynesian, were of a more difficult nature because of the ethnic difference between the two entities. The Ellice islands organised 'a separation before self-government' political stance which was accepted by Great Britain. After a referendum favouring secession with the approval of the United Nations, the Ellice Islanders became constitutionally independent in 1978 and their country took the name of Tuvalu. ${ }^{16}$ Great Britain was to grant independence too to the Gilbert Islands the following year after having solved the difficult problem of the Banaba islanders. The Banabans wanted to secede from the Gilberts and obtain royalties for the phosphates which had been exploited by the British after they were resettled to Rabi Island in Fiji after the Second World War. London did not accept the claim. The Gilbert Islands became the Republic of Kiribati in 1978.

The most complex colonial situation was the Condominium of the New Hebrides : France and Great Britain had jointly ruled from the start of the 20th century this set of Melanesian islands. According to its pro-independence policy towards the Pacific islands in the 1970s, Great Britain was willing to grant independence to the New Hebrides while France was opposed to this move as it could have promoted, if achieved, a similar tendency in other French Pacific Territories of greater strategic interest. Moreover French settlers, especially in Espiritu Santo, were prepared, with the help of some American land speculators, to secede in the late 1970s and found the independent Republic of Vemarana under the authority of a traditional leader, Jimmy Stevens. ${ }^{17}$ The colonial history of Vanuatu had always been a careful balance of national

Ellice Islands are peopled by Polynesians (around 7000 strong in the 1970s) with a total land area of $26 \mathrm{~km}^{2}$ while the Gilbert Islands are peopled by around 50000 Micronesians living on a total land area of $690 \mathrm{~km}^{2}$.

Tuvalu means 'eight together' for the eight islands forming the archipelago ; Tuvalu is an independent State, acknowledging the Queen of the United Kingdom as Head of State, having thus a status of dominion.

17

The South Pacific Forum decided to foster and protect the national integrity of Vanuatu after independence and organized for the sending of military troops from Papua New Guinea to the island of Santo, supervized by Australian officers. 
interest between the two antagonistic colonial powers ${ }^{18}$; the legacy of this rivalry is the emergence today of two separate local entities, wild apart in their political thinking as well as in their ways of seeking the future for the country. Vanuatu was declared independent in July 1980 amidst an intricacy of divergent and antagonostic interests : the catholic francophones on the one side and the anglican-protestant anglophones on the other one. Fifteen years after independence, Vanuatu has not yet come to terms with its colonial legacy.

Thus Great Britain withdrew from Oceania even though ties are maintained with the British Crown. ${ }^{19}$ Only tiny Pitcairn remains today a British colony on historical and humanitarian grounds. ${ }^{20}$ London provided important financial means during the 1970 s to all her former colonies but these means started to progressively diminish in the 1980 s and do not existent any longer nowadays. The majority of them are starving today for financial subsidies which they are trying to secure from international organizations such as EEC, the World Bank or NGO in order to compensate for former British financial subsidies which are now lacking. These independent countries are economically vulnerable and politically fragile and their social development and progress are in a worse state than before constitutional independence.

\section{US Compact of Free Association}

At the turn of the 20th century, the United States acquired Guam, Hawai'i and the eastern part of Samoa. These three territories had a strategic importance (coaling stations, sugar industry for Hawai'i). Hawai'i became the 50th State of the Union in 1959. American Samoa is an unincorporated territory which means that the American Samoans are US nationals without

18 When the two national flags were raised they had both to get up on the pole at the same speed as if one getting up quicker would have implied an outrage to the dignity of the other flag's nation... The Condominium set up two education systems, two health care services, etc. It is interesting to notice that the Ni-Vanuatu preferred to get medical treatment with the British eventhough people had to pay for it while the French health care system was money free. In the people's mind if payment was required meant it was better than the free one. Colonial generosity is not always fully understood.

The former British Pacific countries which have not a republican constitution have thus a governor general who represents the Queen of Great Britain.

20 Pitcairn's population is around 60 people for a total land area of $5 \mathrm{~km}^{2}$; it is on this island that the Bounty mutineers took refuge at the end of the 18th Century. The British governor for Pitcairn is the British High Commissionner in Wellington. 
the right to vote in presidential election. ${ }^{21}$ Guam has the same type of status and is more heavily dependent on the Ministry of Defence for its budget than American Samoa. ${ }^{22}$ These two territories are seeking with the United States some statutory evolution which could grant them, in a not too distant future, more autonomy.

The majority of the Pacific islands, located north of the Equator, had been mandated to Japan under the League of Nations in 1919. After Pearl Harbor, the US sent huge numbers of troops to free these islands from Japanese military presence. When World War Two ended, some American high officials wanted to annex, as a war tribute, these former Japanese Territories in Micronesia because so many American GIs gave their life to take control of them. But, because of the postwar political atmosphere, Washington could not accept as such the annexation of these strategic territories. USSR's presence would have been critical of these new colonies even though Washington had officially declared that these islands were 'not colonies but outposts' for democracy, indispensable for the future of the free world. The Roosevelt Administration decided to avoid any political embarrassment of this nature and placed these Micronesian islands under the aegis of the UN Security Council as strategic trust territories. As such their statutes could never be scrutinized by the UN General Assembly. ${ }^{23}$

The Northern Pacific Islands were then under US supervision while, South of the Equator, American Allies had all archipelagoes under control. There was no real risk of Soviet Union interference. This situation began to change with the constitutional independence of the former British, Australian and New Zealand possessions. The Soviet Union tried to gain influence, unsuccessfully in Tonga in 1976, in paying duties to benefit from harbour's facilities in Nuku'alofa, successfully in Vanuatu and Kiribati later on, even though for limited time. The United States could not afford not to take this Soviet influence into consideration as well as the recent constitutional independence of some island nations which became member of the United

21 It is usually estimated that more than 80000 American Samoans live in Hawai'i and California (they can accede to full American citizenship there) while around 30000 Samoans live in American Samoa, a majority of them originating from Western Samoa.

22 It is from Guam that bombing planes were sent to Vietnam from the 1960s. Today the tourist industry (mainly linked with Japan : more than half a million Japanese visitors in 1990) comes second to military activities in economic and financial importance. With its population of over 130000 (the original inhabitants, the Chamorros, counting for less than $40 \%$ ), Guam is fully urbanised.

23 The United States cannot consider themselves as being a colonial power. It is very seldom that we find an American diplomat or official to admit this fact. It is usually argued that there has never been any colonial Department in Washington as it was the case in Canberra, Paris, London or Wellington. Decolonisation was thus considered to be the business of the colonial powers and there was no need to interfere in internal matters of these allied countries. 
Nations Organisation. Indeed, the populations of the American Trust Territories were attracted by the status of free association which the Cook Islands got with New Zealand and Washington was forced to take into account the Micronesian people's aspirations to manage more their own affairs. Washington did not want such a fragile link with its Micronesian Trust Territories (the cold war situation could not afford it) and offered commonwealth status, which means integration with the United States. American Micronesia was generally perceived as an entity in Washington even though differences in languages, cultures and traditions prevailed among the different archipelagoes. Moreover, Washington attributed higher values to islands of strategic importance (military bases, missile testing, etc.). The Northern Marianas opted for such a status in 1975 and was incorporated into the United States as the Commonwealth of the Northern Mariana Islands in Political Union with the United States. All Mariana Islanders became American citizens when this commonwealth status was implemented and US federal law applied unless being changed by the Commonwealth legislature.

The Marshall Islands and Palau voted against this commonwealth status in 1978 and pressed Washington for an alternative constitution, based on the concept of free association. Free association, it was considered, permitted self-government in all fields of affairs, except in foreign policy matters which could be contrary to US interests as defined by mutual consultations, and in defence matters which are of the sole responsibility of the American federal government. The US were also granted rights to existing military bases for at least 15 years which could be extended by mutual agreement as well as the right to foreclose access to these islands by the military forces of any other country. ${ }^{24}$ This was generally defined in 1978 and it took four more years to draft the constitution precisely because of the complexity of the issues involved : governmental, economic, security and defense relations, marine sovereignty, etc. The four government districts of Pohnpei, Yap, Truk and Kosrae became the third partner to negotiate the compact of free association with Washington as soon as they became the Federated States of Micronesia after the adoption, in 1979, of the Micronesian federal constitution.

In 1982, each of the three Micronesian government signed with Washington a separate Compact of Free Association which were submitted, the following year, to their people by plebiscites under the supervision of UN Trusteeship Council observers. A majority of voters in each of the three territories favoured the Compact and, in 1986, the UN Trusteeship Council approved the American decision to end the trusteeships of the Marshall Islands and the Federated States of Micronesia. In 1990, the UN Security Council dissolved the trust, thus 
favouring the international recognition of the Republic of the Marshall Islands and the Federated States of Micronesia, thus both independent States in free association with the United States. 25

The constitution of Palau ${ }^{26}$ is in opposition with the strategic provisions of the Compact of Free Association with the United States as it does not allow nuclear powered vessels and nuclear weapons through the archipelago without 'the express approval of three-fourths of the votes cast in a referendum submitted on this specific question'. ${ }^{27}$ Several plebiscites have been organized in Palau which resulted in a great majority of voters approving the Compact

25 The Republic of the Marshall Islands has a 33 member parliament (nitijela) which elects a president among its members. The first priority of the new Republic was to secure diplomatic recognition and membership in regional organizations so as to extend relationships away from the United States (Federated States of Micronesia, Kiribati, Papua New Guinea, Australia and New Zealand, the South Pacific Commission, the South Pacific Forum, including the Forum Fisheries Agency in Honiara and the Pacific Forum Line, and the Asian Development Bank. It is seated in the United States General Assembly. While the US and the Marshalls have established an embassy in each other's country, the President of the Republic of the Marshall Islands and the Minister for Foreign Affairs are roving ambassadors as there is no other Marshallese diplomatic post apart from the one in Washington. The Department of State performs diplomatic and consular services on behalf of the Republic upon request. In terms of financial transfers from the US, the Marshall receives around US\$30 million a year under the Compact, an annual rent of around US\$6 million for the use of the Kwajalein missile-testing base and development aid over a number of year for US\$80 million. Washington established a US\$150 million trust fund, the interests of which are going to the Marshallese who suffer from nuclear tests conducted in Bikini, Rongelap, Eniwetok and Utirik from 1946 to 1958. More than US\$ 60 million are allocated to decontaminate these atolls and resettle their inhabitants on other ones. This is presently the case with the inhabitants of Kwajalein who have been resettled on Ebeye Island. The US provide more or less two-third of the Marshallese national budget ; Japan and Australia are financing development programmes in the fishing industry and in road infrastructure. Japan is paying a bit less than US\$1 million for fishing rights.

The Federated States of Micronesia is a sovereign self-governing federation of four constituent states which elect a president among the members of its National Congress. The national policy in terms of Foreign Affairs is more ambitious than in the Marshall with extended linkages within the United Nations system (WHO, UNESCO, UNDP, etc.) and a larger diplomatic network. As with the Marshall, the FSM's national budget mainly comes from financial subsidies from Washington and development aid from Japan, Australia and New Zealand, copra exports and tourism. As in the Marshalls, the FSM leaders are pressing Washington to increase aid. But there are divisions among the representatives of Truk and Pohnpei in the National Congress, the former favouring strong stances against American and Japanese nuclear and chemical dumping. Pohnpei is prepared to secede from the Federated States over this issue, which could imply some conflicting situation with Washington, less aid and some incoherence in terms of diplomatic relations.

26 The Constitution of Palau, which includes non-nuclear clauses, was approved by $78 \%$ of the voters in July 1980 . It came into effect on 1 January 1981 ; it is the first nuclear-free constitution in the world.

27 See Robert Kiste, 'United States' in Tide of History The Pacific Islands in the Twentheith Century above n 6, 234-235 \& Steve Hoadley, The South Pacific Foreign Affairs Handbook (Sydney, Allen \& Unwin, 1992) 136-40. 
agreement without achieving the necessary $75 \%$ which could change the Constitution. This means that the Republic of Palau is self-governing but remains formally a dependency administered by the US Department of the Interior and is not eligible for Compact grants as the Marshall and the Federated States of Micronesia. Although the United Nations Security Council terminated the strategic trust in 1990, the Republic of Palau cannot be formally recognized by other States until the US Senate ratifies the Compact. This requires that Palauans ought to alter their constitution to allow nuclear vessels and weapons in their waters ; but with three-quaters of the votes, this was apparently impossible to achieve. Robert Kiste summarised the situation : 'The Republic of Belau remains in limbo, the last remnant of the trust territory'.28 Financially speaking, Palau remained heavily dependent on the US, like its two American neighbours which benefit from the Compact. ${ }^{29}$ On 1 October 1994, Palau became independent after a judgment of the Supreme Court in Koror, capital of Palau, altered the Constitution in allowing less than $75 \%$ of the population to adopt the compact of free association agreement.

The United States followed the general trend in the Pacific in granting statutory evolution to its possessions in the Pacific. Due to their strategic importance, especially during the cold war era, this very evolution had to be pertained to American strategic interests. It is an irony of history that fifty years after the end of World War II, the majority of these American territories which served as bloody battlegrounds opposing Japanese and American troops, are today invaded by Japanese tourists and investors, regaining an economic and political influence which was lost on military ground.

\section{France : the last colonial power?}

The three French territories in the Pacific seem, at first sight, to have evolved apart from the general trend of the statutory evolutions which the great majority of Pacific island states or territories have achieved.

In a sense, French Polynesia became a strategic territory in 1963 when Charles de Gaulle requested foreign diplomats to leave Tahiti. From then on diplomatic representation to French Polynesia would be assured only by diplomats posted in Paris. ${ }^{30}$ Only New Caledonia was to

Robert Kiste, above n 27, 235.

The Commonwealth of the Mariana Islands now considers that commonwealth status does provide less autonomy in internal and external affairs than the compact as well as lesser financial subsidies from Washington. 
retain an official diplomatic representation for Australia, New Zealand and Indonesia in Noumea.

From 1963, thousands of military personnel, atomic technicians and engineers came to Tahiti, often with their families, to live for a few years. The need for huge military construction compounds and atomic infrastructures in Moruroa and Fangataufa - two Tuamotu atolls -, European-standard accommodation on Hao and in Papeete which served as military bases as well as food from France, had a drastic impact : on the one hand, it transformed the traditional way of life of the Polynesians who left their plantations to work in the construction industry which required labour and, on the other hand, the territorial budget increased tremendously through new customs duties and taxes on all imported materials and products from France. Tahiti rapidly gained the appearance of a wealthy country, in part because French salaries, civil and military, were nearly tripled while metropolitan people lived in French Polynesia. Local salaries soon followed, to avoid discrepancies in incomes. There are no income taxes in French Polynesia but the cost of living is nevertheless very high because of import duties which are needed to run the territory.

The French Polynesian economy depended heavily on military expenditure and its solvency was also at the mercy of the Ministry of Defence. As costs initially engendered by nuclear testing activities were inflationary, they became too heavy for the Ministry of Defence which began, after twenty years of operations, to send military experts and engineers for shorter periods and without their family. The effects on commerce, house rents, import taxes were so negative that French Polynesia was rapidly confronted with a very difficult situation. The Territory was now heavily in debt and Paris does not want to supplement its huge deficits to the same extent as in the past. The suspension of nuclear testing in 1992 exacerbated the situation which confronted French Polynesia, which obtained from Paris, in 1984, a self-governing status, similar to the one which the Cook Islands got from New Zealand. ${ }^{31}$ Because of this status, Paris thinks that French Polynesia should also organise its spending within the limits of the large transfer of public money France organises every year. It is on this very basis that paradoxically, the French Polynesian government is willing to see nuclear testing being restarted again. Even if this is possible in the foreseeable future, it would not last long and it would only prolong the

31 Since 1984, French Polynesia is ruled by a president and ten ministers elected by the 42 Territorial Assembly members, themselves elected by general franchise every four years. All portfolios are in the hands of the territorial government except justice, defense and treasury. In foreign affairs the president of the territorial governement is fully able to sign conventions with other Pacific island states officially recognised by France. 
artificial economy a little before forcing the French Polynesian population to come down to reality.

Wallis and Futuna became a French overseas territory in 1961 after its population wanted, by plebiscites, to abandon its French protectorate status which was existing since the 1880 s. The archipelago has remained very traditional with three kingdoms and three customary governments, ${ }^{32}$ which are officially recognised by France. These two islands do not export anything and they are totally financially supported by Paris for the annual amount of some US\$ 40 million. More than 15000 Wallisians and Futunians are living in New Caledonia.

Like Australia and New Zealand, New Caledonia has been a settler's colony from 1863 onwards. Today it is usually perceived that two communities are living face to face while this French territory is pluriethnic with more than $20 \%$ of the total populations being neither Kanak nor Caldoche $e^{33}$ but Wallisians, Asians, Tahitians, etc. The Kanak are the majority of the population with some $44 \%$ and the Caldoches represent some $33 \%$.

Independence status has been at stake in this territory for nearly twenty years among the two main populations, the Kanak generally want to achieve it while the Caldoches largely want to remain an integral part of France. A series of different statutes were implemented in New Caledonia by Paris since 1963, not to last long and to be accommodated by following ones. Following the bloody events of the 1980s, the Caledonian population will be expected to define, through a referendum, if they want to become constitutionally independent or not. But it is believed that this referendum in 1998 could be postponed as a majority of New Caledonian leaders consider today that independence would not be workable as such without a sufficient elite. The Matignon Agreement has so far produced an economic and political balance between the three provinces even though the Southern one where Noumea is remains the most powerful one. New Caledonia is rich in mineral ore and is the only French territory in the region which could engage in sustainable development if independent.

France has thus postponed the evolutionary process of her three territories in the Pacific. This is due to strategic reasons in French Polynesia, to a democratic expression of choice for its future in New Caledonia, to a constitutional status quo in Wallis and Futuna where one does not find any real wish towards political independence as the archipelago is financially totally

32 One kingdom in Wallis (Uvea) and two in Futuna (Alo and Sigave). Wallis and Futuna have a land area of $200 \mathrm{~km}^{2}$ and a total population of some 14000 . The French expatriates represent less than $2 \%$ of the entire population. 
dependent upon French finances. But France would have to determine for itself what will be the future of its three territories. They are two options if the status quo is to be maintained in terms of links with the metropolis : either a stronger political decentralisation which would allow a better expression of local aspirations or new statutes for each of them, probably in some sort of free association with France if the local populations favour it.

\section{Conclusion}

The Pacific Islands are more and more vulnerable and fragile in the present world of technological advances. Let's consider for example maritime transport : the Islands without real financial means cannot afford the harbour's infrastructure which will allow them to receive container ships and thus cannot be involved in economic exchanges which, in turn, would favour access to what is called 'modernity'.

Decolonisation was the key element from the 1960 s to the 1980 s in the Pacific. Since then no Pacific territory has achieved constitutional independence. Does this mean that something has changed? It is highly probable that finances and social progress count nowadays more than politics.

\section{Processus de décolonisation dans le Pacifique Une analyse comparative entre les puissances métropolitaines}

Les archipels du Pacifique Sud ont accédé tardivement, en comparaison avec l'Asie et l'Afrique, au processus de décolonisation.

C'est la France qui l'a entamé la première en appliquant à ses territories d'outre-mer du Pacifique la loi-cadre Defferre de 1957 qui conduisit les colonies françaises d'Afrique sur la voie de l'indépendance. Des gouvernements autonomes furent élus en Nouvelle-Calédonie comme en Polynésie Française cette même année. Mais ils sont abolis en 1963 lorsque le général de Faulle, après son retour au pouvoir, décida d'implanter le centre d'expérimentation nucléaire à Moruroa. De cette date à aujourd'hui, un statu quo ante a persisté au plan statutaire, vecteur de crises et de tensions, principalement en Nouvelle-Calédonie. L'évolution politique des territories française du Pacifique, incluant Wallis \& Futuna, est ici analysée.

La Grande-Bretagne, l'Australie et la Nouvelle-Zélande se sont conformées aux recommendations du Comité de décolonisation des Nations-Unies en matière de décolonisation, à savoir d'accorder l'indeependance constitutionnelle aux territories, de les intégrer à la 
métropole ou encore de les engager à former des gouvernements autonomes en association libre avec l'ancienne puissance coloniale.

Le Royaume-Uni attribua l'indépendance constitutionnelle à toutes ses colonies du Pacifique, sauf à Pitcairn pour des raisons particulières. Les raisons sous-tendant cette décision sont analysées ici en fonction du contexte britannique des années 1970, culminant dans la difficile indépendance de Vanuatu en juillet 1980.

La Nouvelle-Zélande et l'Australie ont suivi les recommendations de l'ONU et ont accordé l'indépendance ou l'autonomie gouvernementale à leurs territoires colonisés. Dans le même temps, ces deux pays ont renforcé leur potentiel de domination dans le Pacifique Sud dans le contexte géopolitique malaisé des années 1980.

La Micronésie américaine a connu une évolution statutaire au travers de son cadre stratégique, examiné en détail dans cet article.

Ce qui est en jeu aujourd'hui dans l'ensemble du Pacifique insulaire ne relève sans doute plus du fait politique mais bien de l'économique et du financier. 